\title{
COMPARISON OF GALA MUST APPLE QUALITY GROWN ON DIFFERENT TREE TRELLISES
}

\author{
Author(s): \\ Gy. Csima ${ }^{1}$ - Zs. Varga1 - G. Ficzek² - I. G. Gyökös² - Z. Láng ${ }^{1}$
}

Affiliation:

${ }^{1}$ Technical Department, Faculty of Horticultural Sciences, Corvinus University of Budapest, Villányi street 29-43., H-1118 2Department of Pomology, Faculty of Horticultural Sciences, Corvinus University of Budapest, Villányi street 29-43., H-1118

Email address:

gyorgy.csima@uni-corvinus.hu, zsofia.varga@uni-corvinus.hu, gitta.ficzek@uni-corvinus.hu, imregergo.gyokos@uni-corvinus.hu, zoltan.lang@uni-corvinus.hu

\begin{abstract}
The aim of this project was to compare the effect of different trellises (slender spindle, V-system and an experimental Y shape trellises) on some quality parameters of fresh market 'Regal Prince' (Syn. Gala Must) apples, which were grafted on M.9 dwarfing rootstocks. It was found that the Y-shape trellis has grown the largest and most uniform size apples meanwhile the yield per hectare was similar to that of $\mathrm{V}$ system. The higher cover color coverage rate, which increases the selling price, the less firmness, the higher solid (sugar) content, the earliness are in favour of Y-shape trellis.
\end{abstract}

\section{Keywords:}

trellis, apple size, quality, yield, 'Regal Prince'

\section{Introduction}

The increasing competition in the market and the changing preferences of consumers are resulting in increased demand for excellent quality apple (Malus $\times$ domestica Borkh.) fruits [1]. In the main apple producing countries of the world 'Gala' is favored by both growers and consumers, but in the European apple producing countries the size and color of fruits do not develop until the optimal harvest date, which often causes trouble. Because of this the harvest is often delayed, nevertheless it have negative effect on fruit quality (flesh firmness, storability), and it increases the risk of fruit crack [2].

Use of trellises enable advantageous limb structure of branches (optimal assimilation) in one (or more) plane(s), so prevent damages due to strong wind and increase early production. It is important to note, that the position of fruits inside the canopy basically affects fruit development, especially the development of size and color [3]. And last, but not least, the use of trellises make easier the chemical plant protection and handling of plants (pruning, thinning, etc.), ease the automation of irrigation and fertilization and enables the mechanization of harvesting $[4,5,6,7]$. Higher returns due to early production of high density apple orchards are breaking even in 6-7 years compared to 10-12 years for traditional plantations. The trellises are usually constructed in "V" shape [8], but it seems to be the most successful a single plane of posts with 2-4 wires. The effect of different canopy shapes to yield were compared in preview studies in case of 'Golden Delicious' [9], 'Royal Gala' [9, 10]; and Jonagold' [11].

\section{Materials and methods}

\section{Experimental plantation}

Experiments were started in 2007 in Hungary on a newly planted orchard plot in the near of Soroksár on 0.1755 ha on the experimental farm of Corvinus University of Budapest. The aims were to reduce manpower demand by using special tools and machines in delicious quality apple plantation and also to grow larger and more uniform size fruits.

The plantation was divided in three plots. In the first plot 'Regal Prince' (Syn. Gala Must) saplings on M.9 rootstock were grown on V-system (V shaped) trellis on 0.054 ha, in the second one the same type apple saplings were grown on slender spindle (I shaped) trellis on 0.054 ha and in the third plot also Gala Must saplings were grown on a new trellis, called Y shaped (Figure 1) on 0.0675 ha. To distinguish the trellises the slender spindle trellis by I, the V-system was marked by the letter V and the new trellis by $Y$. In case of Y-shape trellis the consoles of with incline in 20 grade to the horizon were fitted on both sides of the central poles. The saplings fixed on $\mathrm{Y}$ canopy to the wires alternately to the left and right (see Figure 1.).

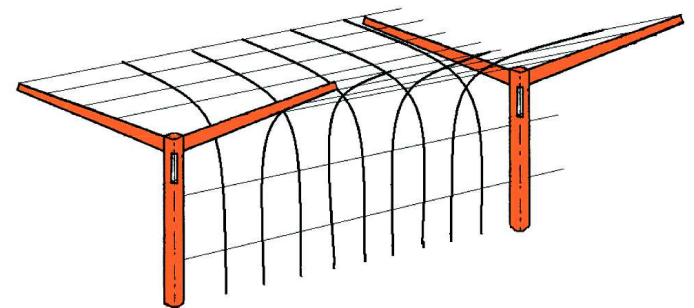

Figure 1. Schematic view of experimental Y-shape trellis system

In each plot 3 rows of $50 \mathrm{~m}$ length was planted, with row distances of $3.6 \mathrm{~m}, 3.6 \mathrm{~m}$ and $4.5 \mathrm{~m}$ respectively. This last one because of the post width of $2.9 \mathrm{~m}$ at the $\mathrm{Y}$ shaped trellis (Figure 2., right). Plant distances in the row were $50 \mathrm{~cm}$ for $\mathrm{Y}$ shape canopy and V-system and $100 \mathrm{~cm}$ for slender spindle trellis. (see Figure 2.). The saplings were fixed to the wires in all trellises. Figure 2 shows the arrangement of saplings in the row of $Y$ canopy. 

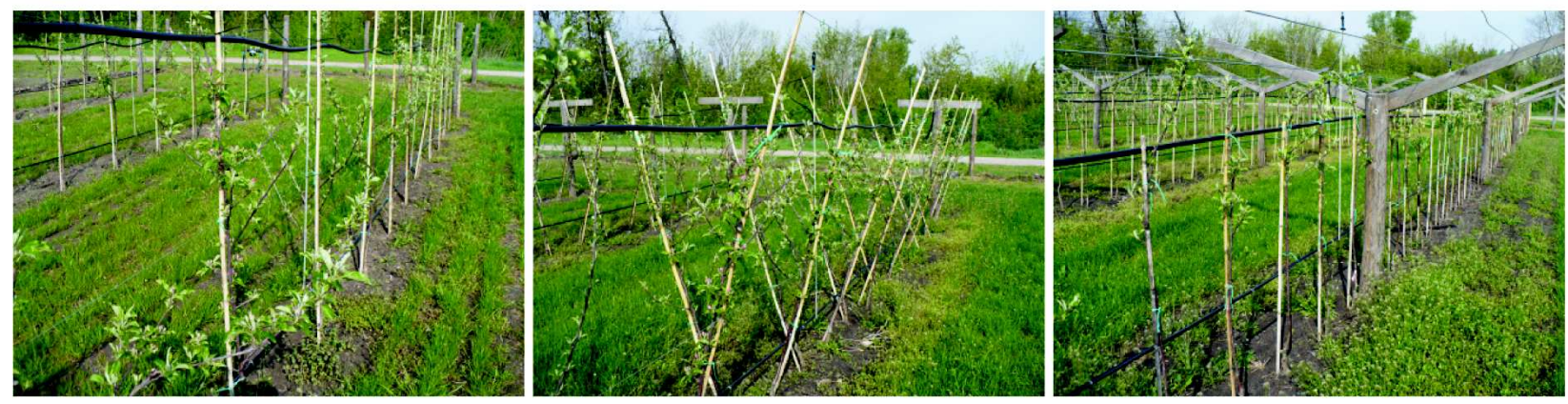

Figure 2. Slender spindle, V-system and Y shaped trellises after plantation in 2007

To be able to compare the three growing systems, in each plot the same treatment was applied for all trees (mulching, spraying, nutrition, irrigation, etc.). The tools and machines - a new top and bottom boom sprayer with droplet collecting plat, a mower adaptor for pre-pruning and a tractor town harvesting platform were already tested $[12,13]$. In this paper the value and yield of apples grown on the three trellis system are compared.

Yield measuring started already in the second year. Seven years after plantation, in the 2014 season, between 22.08. and 02.09 a series of tests were carried out including the measurement of main geometrical sizes, size distribution, fruit masses, basic and cover color, rupture stress, as well as total soluble solid (Brix\%) and acid content of the fruits. Yield per tree and per hectare was also measured for each trellis.

\section{Performed tests}

For the estimation of yield fruits were harvested from the $5 \%$ of the saplings from each type of trellises. All the picked fruits were taken in view. For the quality characterization 34 apples were picked randomly from each row (3) of each type of trellises (3), which gave 102 fruits from each type of trellises and altogether $34 * 9=306$ fruits from the plantation.

On each fruit the largest and smallest meridian diameter as well as fruit height was measured in $\mathrm{mm}$ with a $0.01 \mathrm{~mm}$ resolution Mitutoyo CD-15DC digital caliper. The harvested apples were sorted in 4 diameter groups: $75 \mathrm{~mm}$ and above; between $65 \mathrm{~mm}$ and $75 \mathrm{~mm}$; between 55 and $65 \mathrm{~mm}$, and smaller than $55 \mathrm{~mm}$ to find the distribution pattern for the three trellises.

The basic and cover color stimulus components (X, Y, and Z) of the harvested samples were measured with a Colorlite sph 850 spectrophotometer on each fruit. From he recorded data the $\mathrm{L}^{*}$, $\mathrm{a}^{*}$ and $\mathrm{b}^{*}$ values were calculated according to CIE 1976 color measurement standards [14]. The basic and cover color was compared in case of each trellis.

The fruit firmness was measured on the half of the samples, both on sunny and shady side of the apples with an Effegi FT-011 manual penetrometer [15] with a cylinder probe of $7 / 16$ " (approximately 11,09 $\mathrm{mm}$ ) diameter.

From each row 17 apples were milled and mixed with a juicer. From the juice the total titratable acidity with three times of repetition for each row was determined in \% malic acid with 0,1 n NaOH solution based on MSZ EN Nr 12147:1998 Hungarian Standard.

The total soluble solids (Brix\%) was determined based on CODEX ALIMENTARIUS 3-1-558/93 formula using ATAGO PR-101 type digital refractometer in Brix\% with three repetitions. The total soluble solid content can be corresponds to the sugar content, which is one of main taste characters. The consumer preference of fresh apple is determined by harmonious taste, which depends principally on sugar/acid ratio $[16,17]$. So the ratio of total soluble solid content to total titratable acid content was calculated. If this ratio is under 15 , the apple contains too much acid and or little sugar, so it is not comfortable for consumers. If this ratio value is high, above 25 , the apple is sweet, but it contains very few acids, so it will lose its taste during storage, it is good only for fresh consumption.

\section{Results and discussion}

The fruit size distributions of the 34-34 apples from each row of each trellis (Figure 3.) clearly shows that the characteristic mean diameter of fruits harvested from experimental Y-shape trellis are significantly bigger, than in case of V-system and slender spindle trellis.

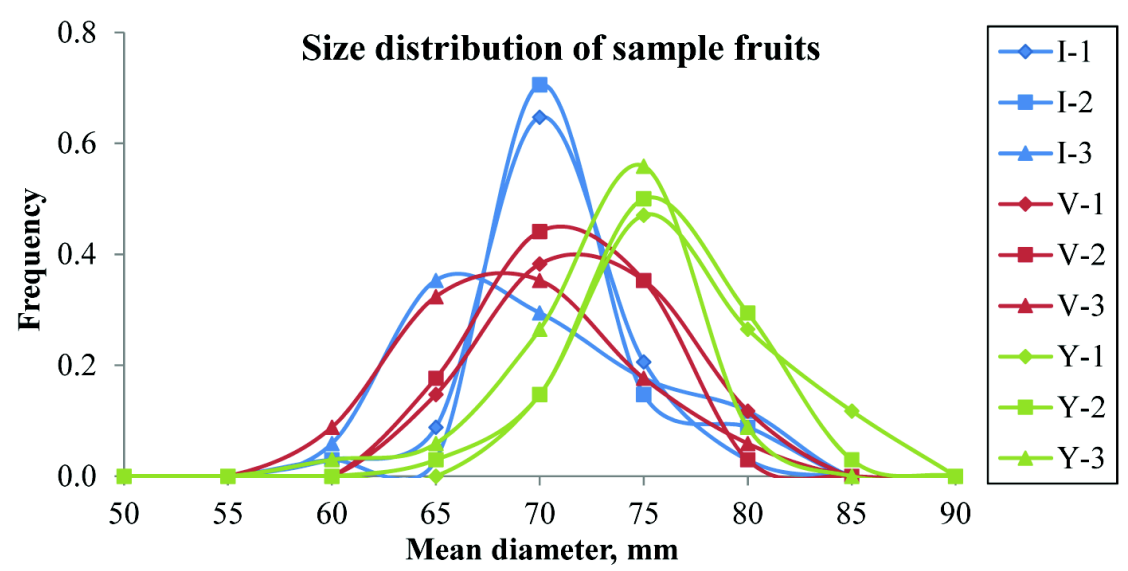

Figure 3. Mean diameter distribution of 'Gala Must' apples grown on different trellises 
All the harvested apples were classified by mean diameter into four groups before storing and selling: $<55 \mathrm{~mm}$ (for juice); $55-$ $65 \mathrm{~mm}$; $65-75 \mathrm{~mm}$; and $>75 \mathrm{~mm}$. The size distribution of the harvested quantity (approximately 6 tones from the whole experimental plantation) is shown on Figure 4. From the illustrated data clearly seems, that the size distribution of Y-shape trellis is more homogenous between the three rows, than in case of V-system trellis. The slender spindle trellis also resulted uniform fruit size apples, but those apples were smaller, than the fruits grown on Y-shape trellis. Furthermore on Y-shape trellis the ratio of diameter sizes $55-65 \mathrm{~mm}$ and size under $55 \mathrm{~mm}$ to other size groups were the least.

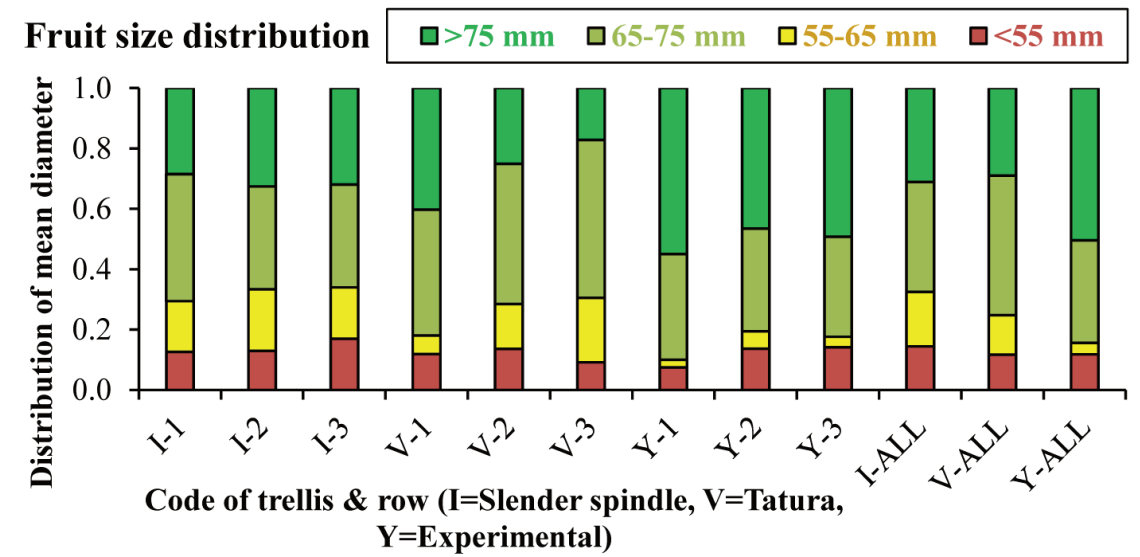

Figure 4. Mean diameter size distribution of 'Gala Must' apples grown on different trellises

The change of specific yields of applied trellises between 2008 and 2014 are illustrated on Figure 5. According to our results, on the V-system trellis the yield is clearly higher, than on slender spindle trellis contrary the results of Mika and Piskor [18], who found no significant difference between V-system and super spindle. The estimated specific proceeds were calculated also for
1 ha area for the three trellises as illustrated on Figure 6. The value of $\mathrm{V}$-system is a little higher than that of Y shape trellis. The reason for the handicap of Y-shape canopy is, despite higher yield per trees and better fruit quality, the larger growing area of it (larger row distances)

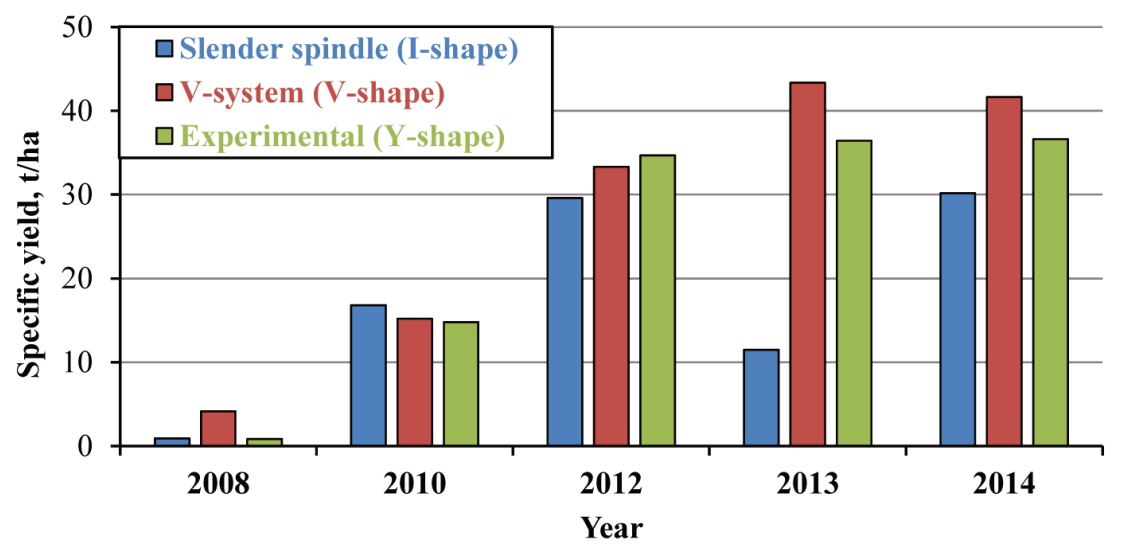

Figure 5. Change of specific yields of 'Gala Must' apple grown on applied trellises between 2008 and 2014

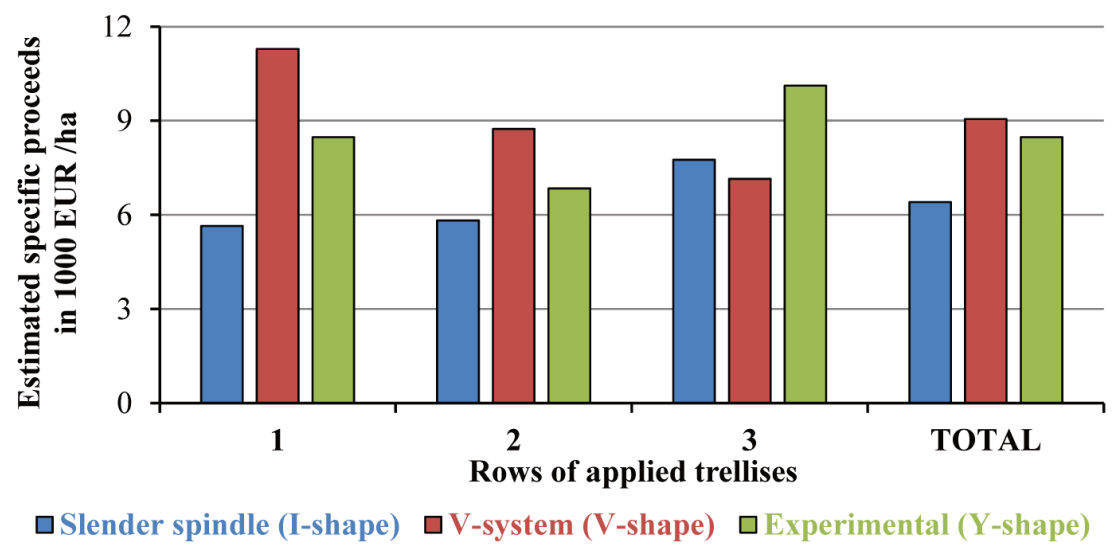

Figure 6. Estimated specific proceeds of applied trellises for 1 ha plantation area (based on the moderate HUF-EUR exchange rate of the Hungarian National Bank for term 09.01.2014. $-12.31 .2014 .: 1 \mathrm{EUR}=312.24 \mathrm{HUF}$ ) 
The CIE L*, $a^{*} b^{*}$ color parameters (Figure 7.) shows the little, not significant difference between apples growing on the mentioned trellises. The same base color was evidence of applying the same apple cultivar clone. The little differences in cover color refer to different degree of maturity.

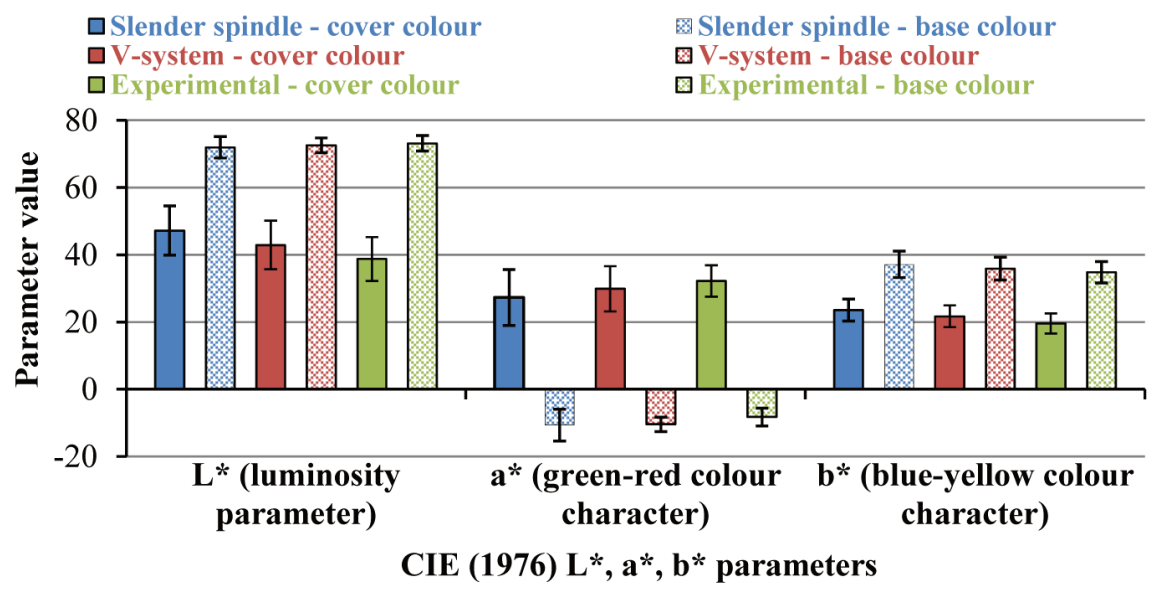

Figure 7. CIE (1976) L*, a*, b* color parameters of 'Gala Must' apples growing on different type of trellises.

Comparing the rupture stress data results (Fig. 8.), it is clear, that the fruits grown on Y-shape trellis are in average a little softer, compared to the other two trellises. Due to the beneficial canopy design of Y-shape trellis the fruits get more sunshine and light, so the fruits can be harvested earlier.

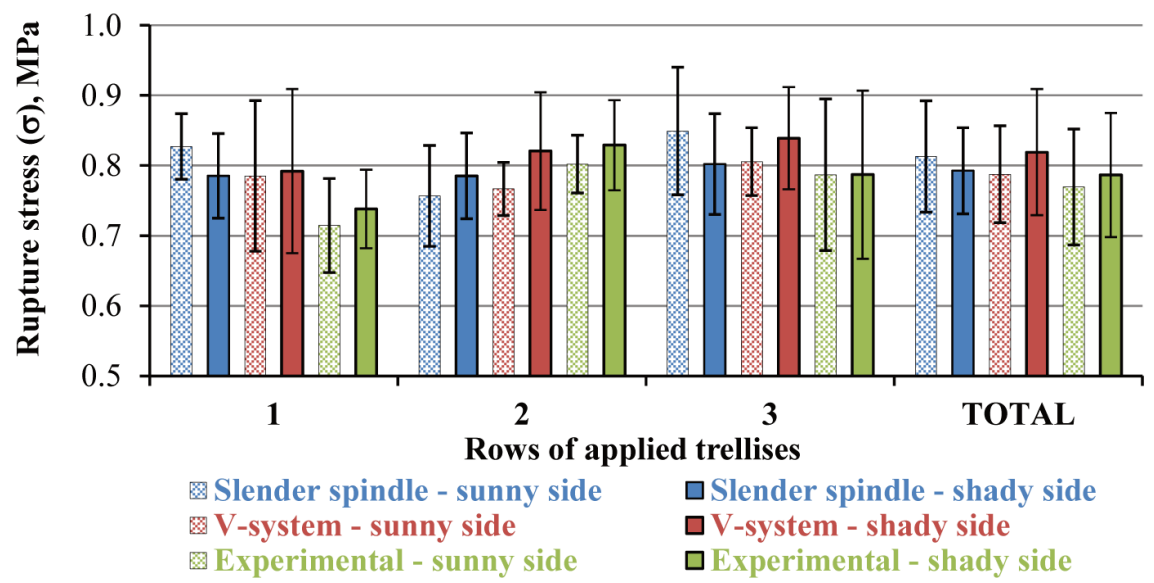

Figure 8. Rupture stress on sunny and shady side of Gala Must apples grown on different type of trellises.

The ratio of total soluble solid content (which corresponds to sugar content) to the total titratable acid content is a good marker for characterizing the taste of apple. The parameter values was about the same for the tested apples, as it seen on Figure 9. There was a little size, but clear difference between the trellises, which referred also to the degree of maturity.

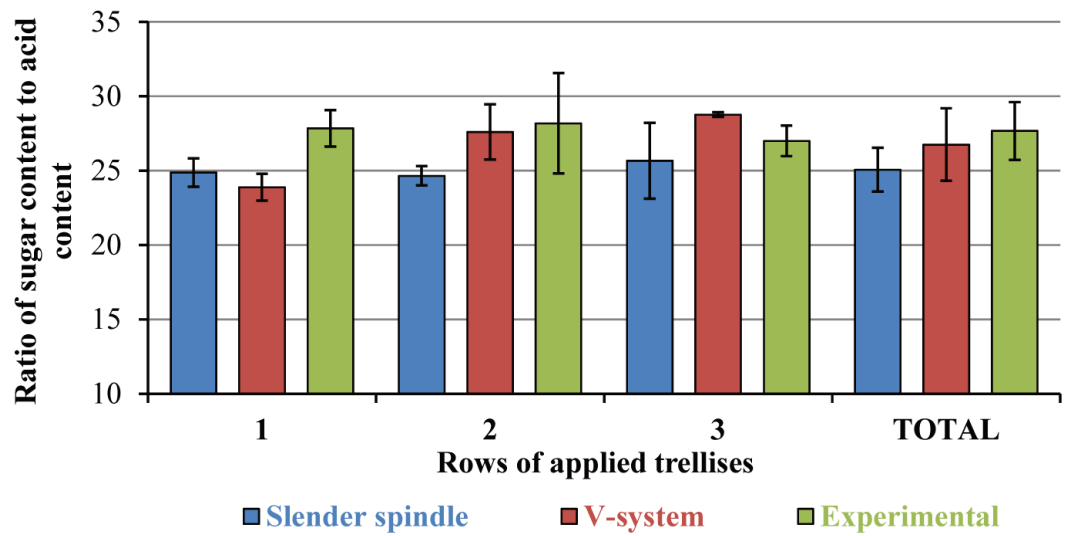

Figure 9. Ratio of sugar content to the acid content of 'Gala Must' apples grown on different type of trellises 


\section{Conclusion}

As a result of the 2014 tests the characteristic mean diameter of Gala Must fruits harvested from Y-shape trellis are significantly larger, the size distribution is more homogenous between the rows, compared with the results on slender spindle and V-system trellis. The specific yield in $\mathrm{t} / \mathrm{ha}$ in 2014 and in most of the previous years was the highest on V-system, followed by the Yshape trellis. The explanation for this is the larger row distance of Y trellis. The higher cover color coverage rate, which increases the selling price, the less firmness, the higher solid (sugar) content, the earliness are in favor of $Y$ trellis. The experimental $\mathrm{Y}$ shape trellis is a good choice for apple growers who want to produce high value apples with less manpower demand.

\section{References}

[1.] Ficzek G., Ladányi M., Radeczky Zs., Tóth M.: 2013. Healthcare values and potential uses of the new Hungarian apple varieties on the basis on fruit analysis, International Journal of Horticultural Sciences, Vol. 19., pp. 25-28.

[2.] Iglesias I., Alegre S.: 2006. The effect of anti-hail nets on fruit protection, radiation, temperature, quality and profitability of 'Mondial Gala' apples, Journal of Applied Horticulture, Vol. 8., pp. 91-100. p.

[3.] Stajnko D., Rozman Č., Pavlovič M., Beber M., Zadravec P.: 2013. Modeling of 'Gala' apple fruits diameter for improving the accuracy of early yield prediction, Scientia Horticulturae, Vol. 160., pp. 306-312. http://dx.doi.org/10.1016/j.scienta.2013.06.003 [4.] Robinson T. L. 2006. Modern apple training systems, The University of Vermont, 2006.

[5.] Fenyvesi L., Fenyvesi D.: 2008. Optimization of a Supporting Device for Mechanical Harvesting, Acta Horticulturae, Vol. 768, pp. 423-430.

[6.] Hegybíró M., Kurtán S., Láng Z., Nagy S., Wieser A.: 2013. Special Technical Knowledge in Horticulture. In: Németh Zámboriné, É., Sárosi, Sz., Horváth, L.: Modern Horticulture. Corvinus University of Budapest, Faculty of Horticultural Science, 2013.

[7.] Robinson T., Hoying S., Sazo M. M., DeMarree A., Dominguez L.: 2013. A Vision for Apple Orchard Systems of the Future, New York Fruit Quaterly, Vol. 21., pp. 11-16.
[8.] Robinson T. L.: 1998. V-Shaped Apple Planting Systems, Acta Hort. (ISHS), Vol. 513. pp. 337-348. h ttp://dx.doi.org/ 10.17660/ActaHortic.1998.513.40

[9.] Widmer A., Krebs C.: 2001. Influence Of Planting Density And Tree Form On Yield And Fruit Quality Of 'Golden Delicious' And 'Royal Gala' Apples, Acta Hort (ISHS), Vol. 557. pp. 235-242.

http://dx.doi.org/10.17660/ActaHortic.2001.557.30

[10.] Hampson C. R., Quamme H. A., Brownlee R. T.: 2002. Canopy Growth, Yield, and Fruit Quality of 'Royal Gala' Apple Trees Grown for Eight Years in Five Tree Training Systems, HortScience, Vol. 37., pp. 627-631.

[11.] Licznar-Malańczuk M.: 2006. Training system and fruit quality in the apple cultivar 'Jonagold', Journal of Fruit and Ornamental Plant Research, Vol. 14. pp. 213-218.

[12.] Láng Z., Kurtán S., Nagy S., Serelegi K., Sinóros-Szabó B.: 2009. Mechanization of fresh market apple production based on a special trellis, Hungarian Agricultural Engineering, Vol. 22., pp. 31-33.

[13.] Láng Z., Serelegi K.: 2010. Apple Production Trials on a Y Shaped Trellises. AgEng2010, the International Conference on Agricultural Engineering, Clermont-Ferrand, France, 6-8. September, 2010, Full paper on PD, Ref 282, 1-4

[14.] Voss D. H.: 1992. Relating colorimeter measurement of plant color to the Royal Horticultural Society Colour, Horticulturer Science, Vol. 27. pp. 1256-1260.

[15.] Abbott J. A.: 1999. Quality measurement of fruits and vegetables, Postharvest Biology and Technology, Vol. 15. pp. 207-225. http://dx.doi.org/10.1016/S0925-5214(98)00086-6

[16.] Vangdal E. 1985. Quality criteria for fruit for fresh consumption, Acta Agriculturae Scandinavica, Vol. 35. pp. 4147.

[17.] Harker F. R., Marsh K. B., Young H., Murray S. H., Gunson F. A.. Walker S. B.: 2002. Sensory interpretation of instrumental measurements 2: sweet and acid taste of apple fruit, Postharvest Biology and Technology, Vol. 24. pp. 241-250. http://dx.doi.org/10.1016/S0925-5214(01)00157-0

[18.] Mika A., Piskor E.: 1997. Growth and cropping of dwarf 'jonagold' ('jonica') apple trees planted at the density ranged from 2,000 to 10,000 per ha and trained as slender spindle, super spindle and V-system, Acta Hort. (ISHS), Vol. 451., pp. 473-478. http://dx.doi.org/10.17660/ActaHortic.1997.451.54 